\title{
Characteristics of accumulated soil carbon and soil respiration in temperate deciduous forest and alpine pastureland
}

\author{
Seok-Hee Jeong ${ }^{1}$, Ji-Young Eom¹, Ju-Yeon Park', Jae-Ho Lee ${ }^{2}$ and Jae-Seok Lee ${ }^{1^{*}}$ (1)
}

\begin{abstract}
Background: For various reasons such as agricultural and economical purposes, land-use changes are rapidly increasing not only in Korea but also in the world, leading to shifts in the characteristics of local carbon cycle. Therefore, in order to understand the large-scale ecosystem carbon cycle, it is necessary first to understand vegetation on this local scale. As a result, it is essential to comprehend change of the carbon balance attributed by the land-use changes. In this study, we attempt to understand accumulated soil carbon (ASC) and soil respiration (Rs) related to carbon cycle in two ecosystems, artificially turned forest into pastureland from forest and a native deciduous temperate forest, resulted from different land-use in the same area.

Results: Rs were shown typical seasonal changes in the alpine pastureland (AP) and temperate deciduous forest (TDF). The annual average Rs was $160.5 \mathrm{mg} \mathrm{CO}_{2} \mathrm{~m}^{-2} \mathrm{~h}^{-1}$ in the AP, but it was $405.1 \mathrm{mg} \mathrm{CO}_{2} \mathrm{~m}^{-2} \mathrm{~h}^{-1}$ in the TDF, indicating that the Rs in the AP was lower about 54\% than that in the TDF. Also, ASC in the AP was $124.49 \mathrm{Mg} C$ $\mathrm{ha}^{-1}$ from litter layer to $30-\mathrm{cm}$ soil depth. The ASC was about $88.9 \mathrm{Mg} \mathrm{Cha}^{-1}$, and it was $71.5 \%$ of that of the AP. The temperature factors in the AP was high about $4{ }^{\circ} \mathrm{C}$ on average compared to the TDF. In AP, it was observed high amount of sunlight entering near the soil surface which is related to high soil temperature is due to low canopy structure. This tendency is due to the smaller emission of organic carbon that is accumulated in the soil, which means a higher ASC in the AP compared to the TDF.

Conclusions: The artificial transformation of natural ecosystems into different ecosystems is proceeding widely in the world as well as Korea. The change in land-use type is caused to make the different characteristics of carbon cycle and storage in same region. For evaluating and predicting the carbon cycle in the vegetation modified by the human activity, it is necessary to understand the carbon cycle and storage characteristics of natural ecosystems and converted ecosystems. In this study, we studied the characteristics of ecosystem carbon cycle using different forms in the same region. The land-use changes from a TDF to AP leads to changes in dominant vegetation. Removal of canopy increased light and temperature conditions and slightly decreased SMC during the growing season. Also, land-use change led to an increase of ASC and decrease of Rs in AP. In terms of ecosystem carbon sequestration, AP showed a greater amount of carbon stored in the soil due to sustained supply of above-ground liters and lower degradation rate (soil respiration) than TDF in the high mountains. This shows that TDF and AP do not have much difference in terms of storage and circulation of carbon because the amount of carbon in the forest biomass is stored in the soil in the AP.
\end{abstract}

Keywords: Alpine pastureland, Land-use changes, Soil respiration, Air/soil temperature, Soil moisture contents, Accumulated soil carbon

\footnotetext{
* Correspondence: jaeseok@konkuk.ac.kr

'Department of Biological Science, Konkuk Universtiy, 05029 Seoul, South Korea

Full list of author information is available at the end of the article
}

\section{Ciomed Central}

(c) The Author(s). 2018 Open Access This article is distributed under the terms of the Creative Commons Attribution 4.0 International License (http://creativecommons.org/licenses/by/4.0/), which permits unrestricted use, distribution, and reproduction in any medium, provided you give appropriate credit to the original author(s) and the source, provide a link to the Creative Commons license, and indicate if changes were made. The Creative Commons Public Domain Dedication waiver (http://creativecommons.org/publicdomain/zero/1.0/) applies to the data made available in this article, unless otherwise stated. 


\section{Background}

Carbon dioxide $\left(\mathrm{CO}_{2}\right)$ concentration in the atmosphere is increasing along with the advance of industrialization and is known to be the cause of climate change, including global warming (Pachauri et al. 2014). Elevating $\mathrm{CO}_{2}$ concentration in the atmosphere can be attributed to the increase in burning fossil fuels due to industrialization and increase in natural emissions of $\mathrm{CO}_{2}$ from terrestrial ecosystems (Protocol 1997). Soil respiration (Rs) accounts for most of natural $\mathrm{CO}_{2}$ emissions from ecosystems, and it is known to release a total of $100 \mathrm{Pg}$ year $^{-1}$ in terrestrial ecosystems (Musselman and Fox 1991). Comprised of respiration from plant roots and microbes in the soil, Rs is a process that occurs in all terrestrial ecosystems, but the quantity and speed of the Rs are different for each ecosystem. Thus, it is necessary to measure and quantify the Rs of various ecosystems. However, there are different kinds of terrestrial ecosystems based on various factors, including geographical characteristics, such as latitude and altitude; climatic characteristics, like boreal, temperate, and tropical climates; and vegetative characteristics, like trees, shrubs, and herbaceous. Therefore, quantification of Rs in various ecosystems is necessary to understand characteristics of Rs in whole terrestrial ecosystem.

Studies on Rs in forest and grassland ecosystems have been conducted by many researchers, resulting in the accumulation of data (Batjes 2014, Jobbágy and Jackson 2000, Musselman and Fox 1991, Ohashi et al. 2000, Dixon et al. 1964, Xu et al. 2015). However, these study results are impeding the utilization of data used to predict the changes to the carbon cycle incurred by the land-use changes, which is being rapidly implemented in various regions of the world in different forms. Despite the situation, there are currently only a small number of studies for understanding the changes in the carbon cycle characteristics caused by the land-use changes.

Changing the land-use by transforming the forest ecosystem into agricultural land, such as pastures or farms, or by reforesting with economic species for social or economic reasons signifies a change in the dominant vegetation for the ecosystem's carbon cycle, which will significantly affect the characteristics of the carbon cycle, such as the net primary production (NPP), soil respiration (Rs), and net ecosystem production (NEP). It will also impact the regional micro-climatic environment and carbon accumulation, both of which affect the characteristics of the carbon cycle, resulting in changes to the quantity and the speed of the ecosystem's carbon cycle. This will in turn have an effect on the local carbon cycle and ultimately alter the ecosystem's carbon cycle at a global scale (Houghton 1999). Therefore, it is a very important to collect data and conduct studies on the changing carbon cycle caused by the land-use changes in order to understand the characteristics of the terrestrial ecosystems' carbon cycle.

To identify the characteristics of carbon cycle resulting from the land-use changes in region, it is necessary to understand the different functions of vegetation that influence the carbon cycle as well as appreciate the micro-climatic elements that have an important impact on the carbon cycle (Suseela et al. 2012). Vegetation in the forest ecosystem differs from that in the grassland ecosystem. The forest ecosystem is dominated by woody plants while the grassland ecosystem is dominated by herbaceous. The difference in vegetation is closely related to the ecosystem accumulate carbon. The aboveground biomass carbon accounts for a large percentage of the total carbon accumulation in the forest ecosystem (Dixon et al. 1994) whereas carbon is mostly accumulated in the soil instead of above-ground in the grassland ecosystem (Wang et al. 2002). The above-ground biomass carbon in the forest ecosystem accumulates in the soil in the form of litter, but the speed of accumulation is slower than that in the grassland ecosystem and the circulated amount is very small compared to the total above-ground biomass carbon (Luyssaert et al. 2008). Therefore, it is important to have an understanding of the fact that the different forms of carbon accumulation based on an ecosystem's vegetation have an impact on the amount and the speed of carbon accumulation in the soil, which in turn affects the whole carbon cycle of the ecosystem.

Also, the grassland ecosystem does not have a developed canopy in comparison to the forest ecosystem due to the dominance of herbaceous plants, causing the temperature to fluctuate inside the ecosystem owing to sunlight. Changes in the soil moisture content (SMC) are also extreme due to precipitation and drought (White et al. 2000). The instability caused by the environmental elements in the grassland ecosystem affects the vegetation, which in turn influences the carbon cycle at the ecosystem level. On the other hand, the forest ecosystem has a developed canopy, meaning the amount of sunlight absorbed into the soil is very small compared to the grassland ecosystem. Fluctuation in temperature is also smaller than that in the grassland ecosystem, and the changes in SMC caused by precipitation are stable as well (Vesterdal et al. 2012). Since above-ground vegetation continues to live regardless of seasonal changes, the level of instability is lower in the grassland ecosystem despite alternating external environmental factors, and the amount of litter into the soil is bigger in the grassland ecosystem (Michelsen et al. 2004).

Therefore, the micro-climatic elements involved in the carbon cycle of the forest and grassland ecosystems are distinctively different based on the land-use, and the characteristics of each ecosystem's carbon cycle vary 
accordingly. It is necessary that an accurate quantification of the change in the carbon cycle incurred by the shift in land-use changes from forest to grassland.

In this study, we measured the Rs for comparison of carbon cycle in TDF and AP. Also, we measured environmental factors of the temperate deciduous forest and the pastureland ecosystem. These are important factors in the ecosystem carbon cycle. Thus, we attempted to correlate between the changing environmental factors and Rs resulting from the land-use change.

\section{Methods}

\section{Site description}

The study site is an AP conducted in 1956 and located in Daegwanryeong, Gangwon province ( $37^{\circ} 41^{\prime} 05.7^{\prime \prime} \mathrm{N}$ $128^{\circ} 44^{\prime} 04.7^{\prime \prime}$ E) in Korea. The site was at $840 \mathrm{~m}$, the annual mean temperature is $6.6{ }^{\circ} \mathrm{C}$, and annual mean precipitation is $1989 \mathrm{~mm}$ for the last 30 years (19812010) (Climatological Normals of Korea 2011). The TDF is dominated by Quercus genus such as Quercus mongolica and Quercus serrata. The AP is dominated by Poa pratensis and Festuca ovina. Also, there is a distribution of herbaceous plants, such as Artemisia princeps and Rumex acetosella. The study site is located in the temperate northern climate zone and middle regions of floristics (Noh et al. 2013). Some vegetation in the AP is not naturally dominant (Noh et al. 2013) and is only artificially maintained in the grazing land, which was created through the cultivation of the TDF. Natural grazing was implemented from July 14 to September 4 during the summer season, when the vegetation grows to its fullest during the year.

\section{Soil respiration}

Measurement plot of $20 \mathrm{~m} \times 10 \mathrm{~m}$ was installed in the $\mathrm{AP}$, and three chambers were conducted in the plot to measure the amount of Rs. Rs amount was calculated through the automatic opening and closing chamber (AOCC) system based on a closed-dynamic chamber method (Suh et al. 2006). The AOCC system is composed of the chamber, the pumping, and the power, and the chamber installed in soil surface automatically and rotationally opened and closed every $10 \mathrm{~min}$. The chamber was comprised of a chamber made of stainless steel and a motor controlling the opening and the closing. The pumping unit circulated the air in the chamber sealed from the atmosphere, and the power unit supplied power at certain times to the whole system, including the air pump, motor, and timer. By measuring the $\mathrm{CO}_{2}$ concentration within the chamber for $10 \mathrm{~min}$, the Rs was calculated based on the rate of concentration change per unit area. Rs in the TDF was also manually collected, approximately $250 \mathrm{~m}$ away from the AP site. Six acrylic collars $(\emptyset=16)$ were installed in the plot per measurement area, and by using the $\mathrm{CO}_{2}$ concentration measurement sensor (GMP343, Vaisala, Vantaa, Finland), the Rs in the TDF was calculated regularly once a month based on the closed chamber method, to estimate the amount of $\mathrm{CO}_{2}$ flux from the soil. And these data were used to calculate the soil carbon flux rate based on:

$$
S R\left(\mathrm{mg} \mathrm{CO}_{2} \mathrm{~m}^{-2} \mathrm{~h}^{-1}\right)=a \rho V \mathrm{~A}^{-1}
$$

(a: $\mathrm{CO}_{2}$ rate of increasing (ppm $\mathrm{min}^{-1}$ ), $\rho: \mathrm{CO}_{2}$ density $\left(\mathrm{mg} \mathrm{m}^{-3}\right), V$ : collar volume $\left(\mathrm{m}^{3}\right), S$ : soil surface area $\left.\left(\mathrm{m}^{2}\right)\right)$

While there could be a margin of error based on which method was used to measure Rs, no significant value arose from the different methods used in measuring Rs in the AP and the TDF, according to (Pumpanen et al. 2004). Also, we measured Rs during the growing season (May-November). Therefore, the non-growing season data were gap-filled using the temperature data from study site and exponential correlation between temperature and the Rs.

\section{Soil carbon}

Soil samples were taken from the research areas in the AP and the TDF in September of 2015 and 2016. Three plots were randomly chosen within each research area, where soil was collected from soil deeps of $0-5,5-10$, $10-15,15-20,20-25$, and $25-30 \mathrm{~cm}$ using the soil core (Ø $5 \mathrm{~cm} \times \mathrm{H} 5.1 \mathrm{~cm}$ diameter, stainless steel). The soil was dried for about $72 \mathrm{~h}$ at $80{ }^{\circ} \mathrm{C}$, after which it was weighed to calculate soil density. The organic matter content was measured by ignition method. The dried soil $(<2 \mathrm{~mm})$ was burned in electric furnace at $650{ }^{\circ} \mathrm{C}$ for about $4 \mathrm{~h}$, and it was weighted. The method in Wang et al. (2006) was used to calculate the ASC of the research areas in the AP and the TDF.

\section{Environmental factors}

An environmental factor such as soil temperature (Ts), air temperature $(\mathrm{Ta})$, light intensity, soil moisture content, and precipitation collection system to measure the environmental factors of the AP and the TDF was installed and collected data. TDR sensors (CS616, Campbell Scientific Inc., USA) were installed in two spots close to the Rs chamber between 0 and $15 \mathrm{~cm}$ to monitor the SMC of the research area in the artificial AP. The Ts was measured at $5 \mathrm{~cm}$ depth with a T-type thermo-couple (T-CC, $0.32 \mathrm{~mm}$, Ninomiya). Also, we measured photon density with a PAR sensor (S-LIAM003, Onset, Bourne, USA). The environmental factors of the TDF were measured using a soil moisture sensor (S-SMD-M005, Onset, Bourne, USA), a temperature sensor (S-TMB-M002, Onset, Bourne, USA), and a PPFD sensor (S-LIA-M003, Onset, Bourne, USA), and 
the data from these sensors were saved on a data logger (H21-002, Onset, Bourne, USA).

\section{Results}

\section{Soil respiration}

Rs of the AP were shown typical seasonal changes where it was generally low during the winter and high in the summer (Fig. 1). The lowest value in the winter season was taken on January 24, 2016, at $21.1 \mathrm{mg} \mathrm{CO}_{2} \mathrm{~m}^{-2} \mathrm{~h}^{-1}$, and the highest in summer on July 23, 2015, at $693.7 \mathrm{mg} \mathrm{CO}_{2}$ $\mathrm{m}^{-2} \mathrm{~h}^{-1}$. The average Rs was $323.6 \mathrm{mg} \mathrm{CO} \mathrm{m}^{-2} \mathrm{~h}^{-1}$ during summer and $65.1 \mathrm{mg} \mathrm{CO} \mathrm{m}^{-2} \mathrm{~h}^{-1}$ during winter; the average in summer was about fivefolds the amount of that in winter. Also, the average Rs for the research period was $160.5 \mathrm{mg} \mathrm{CO}_{2} \mathrm{~m}^{-2} \mathrm{~h}^{-1}$.

Seasonal changes could also be observed in the Rs of the TDF (Fig. 2). The highest value was observed in August 2016 at $728.8 \mathrm{mg} \mathrm{CO}_{2} \mathrm{~m}^{-2} \mathrm{~h}^{-1}$ and the lowest in May 2015 at $173.3 \mathrm{mg} \mathrm{CO}_{2} \mathrm{~m}^{-2} \mathrm{~h}^{-1}$. The average Rs for the research period was $405.1 \mathrm{mg} \mathrm{CO}_{2} \mathrm{~m}^{-2} \mathrm{~h}^{-1}$. The Rs was increased during the summer months. Also, the difference of Rs between each measurement plot was increased while it was decreased during the winter season. With monthly Rs in the AP and the TDF during the same period, it could be seen that the respiration in the AP was on average $54 \%$ of that in the TDF (Fig. 3). It could also be observed that there was a tendency for the gap between the Rs in the AP and the TDF to widen during the hot summer days and narrow during the winter days when the temperature fell. The gap was at $0.06 \mathrm{Mg} \mathrm{C} \mathrm{ha}{ }^{-1}$ month $^{-1}$ in May 2015, but it was increased to $0.29 \mathrm{MgC} \mathrm{ha}{ }^{-1}$ month $^{-1}$ in August 2015. It was rapidly decreased again to $0.08 \mathrm{Mg} \mathrm{C} \mathrm{ha}^{-1}$ month $^{-1}$ in September 2015. The same trends were observed in 2016.

\section{Accumulated soil carbon}

ASC in AP was $124.5 \mathrm{Mg} \mathrm{C}$ ha $^{-1}$ from litter layer to 30-cm soil depth (Fig. 4). The upper part closed to the soil surface accumulated the most carbon with 23 and 23.7 $\mathrm{Mg} \mathrm{C} \mathrm{ha}^{-1}$ between $0-5$ and $5-10 \mathrm{~cm}$, respectively. Also, in each of 10-15, 15-20, 20-25, and 25-30 cm, it was 20.7, 19.6, 17.8, and $17.6 \mathrm{Mg} \mathrm{C}^{-1}$, respectively (Fig. 4). Carbon accumulation in the litter layer was at $3.3 \mathrm{MgC} \mathrm{ha}{ }^{-1}$.

On the other hand, the ASC in the TDF was lower than that in the AP in all layers except the litter layer. Like the $\mathrm{AP}$, carbon accumulation was the highest in the $0-5 \mathrm{~cm}$ depth, which is closest to the surface, and it decreased the deeper into the soil. Carbon accumulation from the surface to $30 \mathrm{~cm}$ depth into the soil was respectively 17.7 , 16.3, 15.5, 14.0, 13.4, and 12.1 $\mathrm{Mg} \mathrm{C} \mathrm{Ca}^{-1}$ (Fig. 4), and the total carbon accumulation was at $88.9 \mathrm{MgC} \mathrm{ha}^{-1}$, a mere $71.5 \%$ of that of the AP (Fig. 4). Carbon accumulation in the TDF litter layer was $4.6 \mathrm{Mg} \mathrm{C} \mathrm{ha}^{-1}$, which was higher than that in the AP.

\section{Environmental factors}

There are various environmental factors known to influence Rs in an ecosystem, including sunlight, temperature, soil moisture, and precipitation. In this study, we focused on light, Ta, Ts, and SMC in the AP and the TDF. The AP has an open status because of weak canopy. It was observed that the light entering the ecosystem was 22.7 times higher on average in the AP compared to the TDF (Fig. 5). Also, it spiked between June and August in summer and fell going into the winter. In the TDF, photosynthetic photon flux density was highest in March and April before the leaves started to unfold in earnest and rapidly fell afterwards. The decreased amount of light started to increase in October.

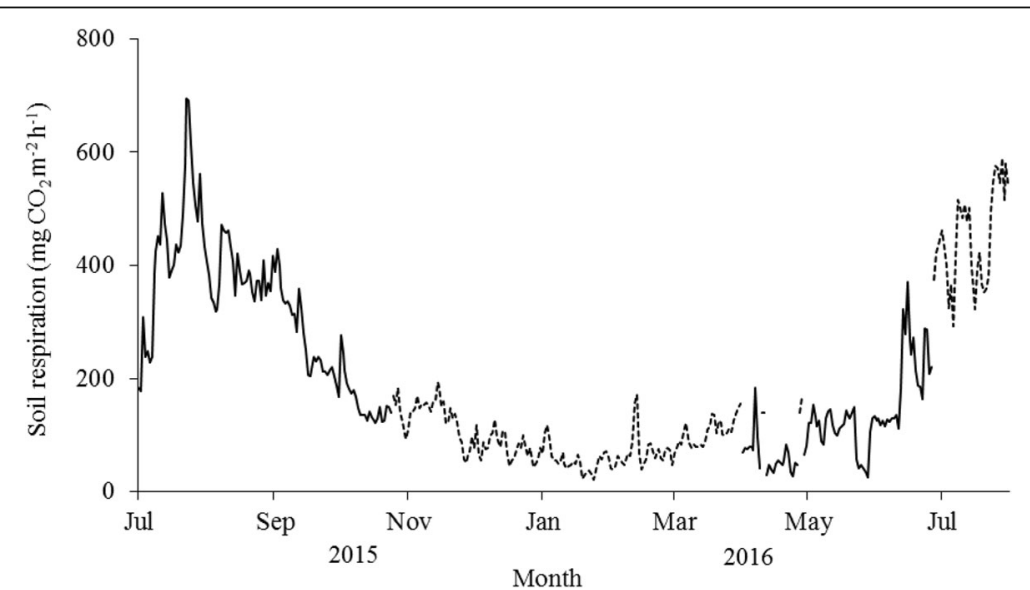

Fig. 1 Variation of soil respiration in alpine pastureland during the study period. The dotted line is the gap-filling data estimated by the exponential correlation between soil respiration and soil temperature 


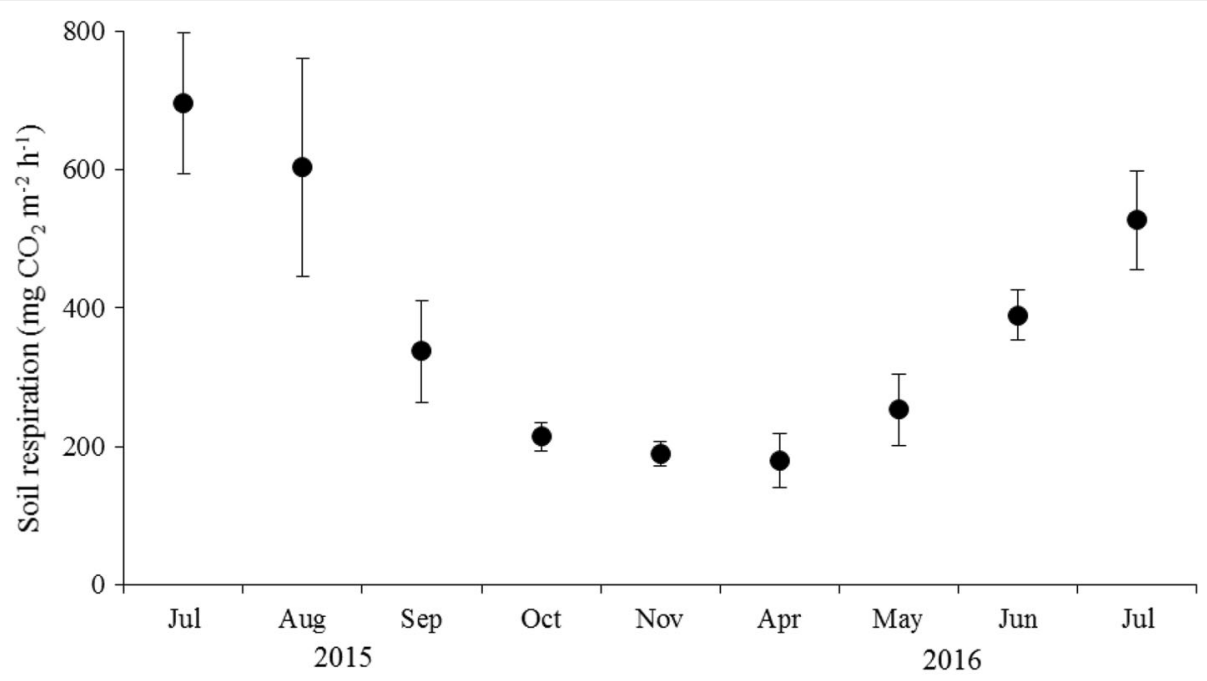

Month

Fig. 2 Variation of soil respiration in temperate deciduous forest during the study period. The dot is the average of soil respiration from six collars, and vertical bar means standard deviation

Ta and Ts in the AP showed typical seasonal changes just like the changes in photon density. The average Ta and Ts in the AP were 13.0 and $15.3{ }^{\circ} \mathrm{C}$, respectively, and they were 9.1 and $9.7{ }^{\circ} \mathrm{C}$ in the TDF (Fig. 6). The AP showed tendency of a larger difference between the Ta and the Ts than that of the TDF. Also, the temperature factors in the AP was shown high condition by approximately $4{ }^{\circ} \mathrm{C}$ on average compared to the TDF.

$\mathrm{SMC}$ in the AP was at $24 \%$ on average; the highest value was $30 \%$ and the lowest $20 \%$ (Fig. 7). This was influence by the amount of precipitation. Considering the characteristics of the climate in Korea, which is influenced by the monsoon season, precipitation was focused in the summer period. SMC in the TDF also was changed with the amount of rainfall, and its average was $22 \%$, which is lower than the average in the AP by $2 \%$. SMC during the growth period in both sites was observed to be equal at an average of $24 \%$.

An analysis was conducted on the relationship between the environmental factors and Rs by examining the correlation between Rs and Ta, Ts, and SMC in the study site of the AP and the TDF. Based on the correlation analysis of Rs and temperature in the TDF and AP, we observed the exponential relationship between Rs and temperature. The Ts had a higher correlation with Rs than Ta (Fig. 8). On the other hand, the AP showed more correlation in Ta than Ts, and when compared to the TDF, both Ta and Ts had a relatively high correlation. Also, while it was difficult to find any kind of tendency in the correlation between SMC and Rs in the

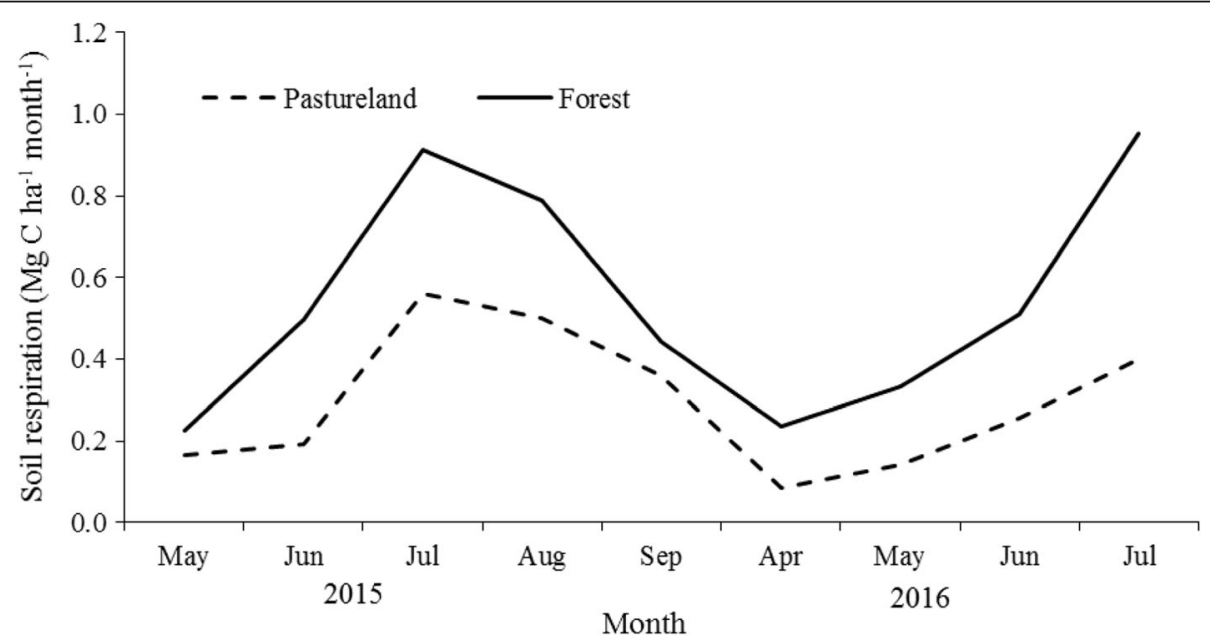

Fig. 3 Comparison of soil respiration in alpine pastureland and temperate deciduous forest 


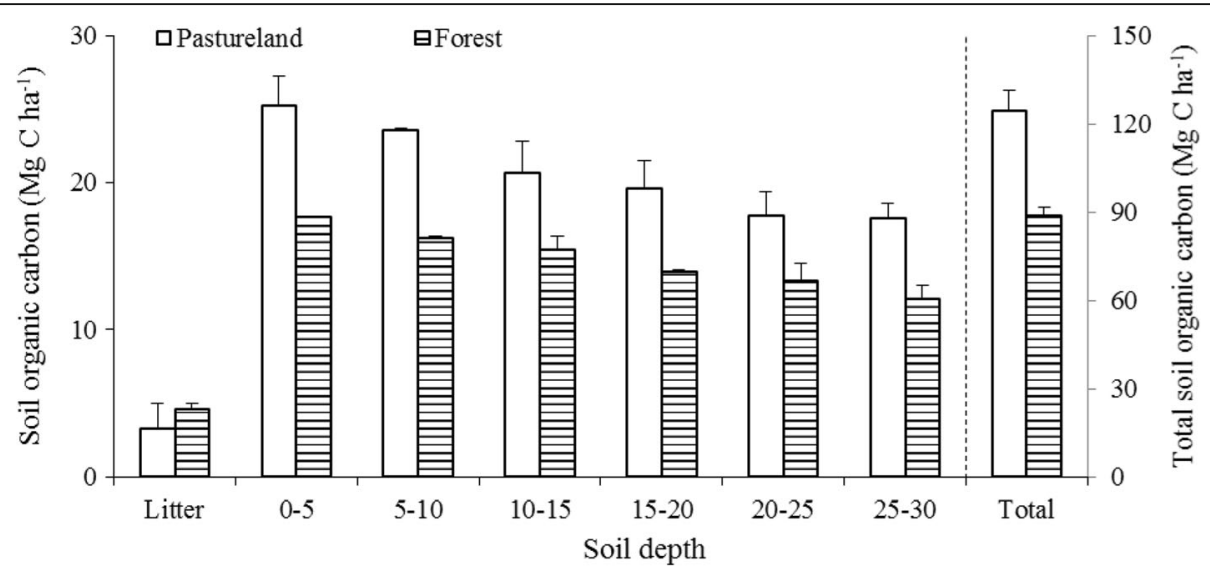

Fig. 4 Accumulated soil organic carbon in soil depths from 0 to $30 \mathrm{~cm}$ in alpine pastureland and temperate deciduous forest. The vertical bar means standard deviation

TDF, the same in the AP showed a linear relation. However, it also showed that an increase in SMC had no special impact in Rs during the non-growth period (Fig. 8).

\section{Discussion}

Rs in terrestrial ecosystems has different characteristics depending on the environmental factors of each ecosystem. The environmental factor that impact Rs is known to be various, including physical and chemical properties of the soil, environmental factors like temperature and SMC, ASC, and dominant vegetation (Raich and Tufekciogul 2000). Temperature is noted to be a very important environmental factor in the below-ground roots and soil microorganism (Lloyd and Taylor 1994). Ts and Rs are especially known to have an exponential correlation (Lloyd and Taylor 1994), which was again demonstrated through this study (Fig. 8). The AP generally had a higher temperature than the TDF (Fig. 6). This is because there is a lot of light entering the ecosystem due to the higher dominance of herbaceous plants in the AP than the TDF (Fig. 5). Since the temperature is higher in the AP than the TDF, other studies have concluded that the grassland ecosystem has higher Rs than the forest ecosystem (Wu et al. 2006). However, this study has shown that Rs was higher in the TDF than in the AP during the whole research period (Fig. 3). This is owing to the fact that there was an environmental factor other than temperature in this study site that had a more significant impact on Rs.

Together with temperature, SMC is known to be a very important factor that impacts Rs; it has a compound effect on Rs with temperature. SMC is also a key factor in the vitality of below-ground roots and microorganism along with temperature, which in turn influences Rs (Wildung et al. 1975, Raich and Tufekciogul 2000). This study observed that the average SMC in the 0 - to $15-\mathrm{cm}$ soil depth was higher in the TDF than that in the AP (Fig. 7). This result can be attributed to the

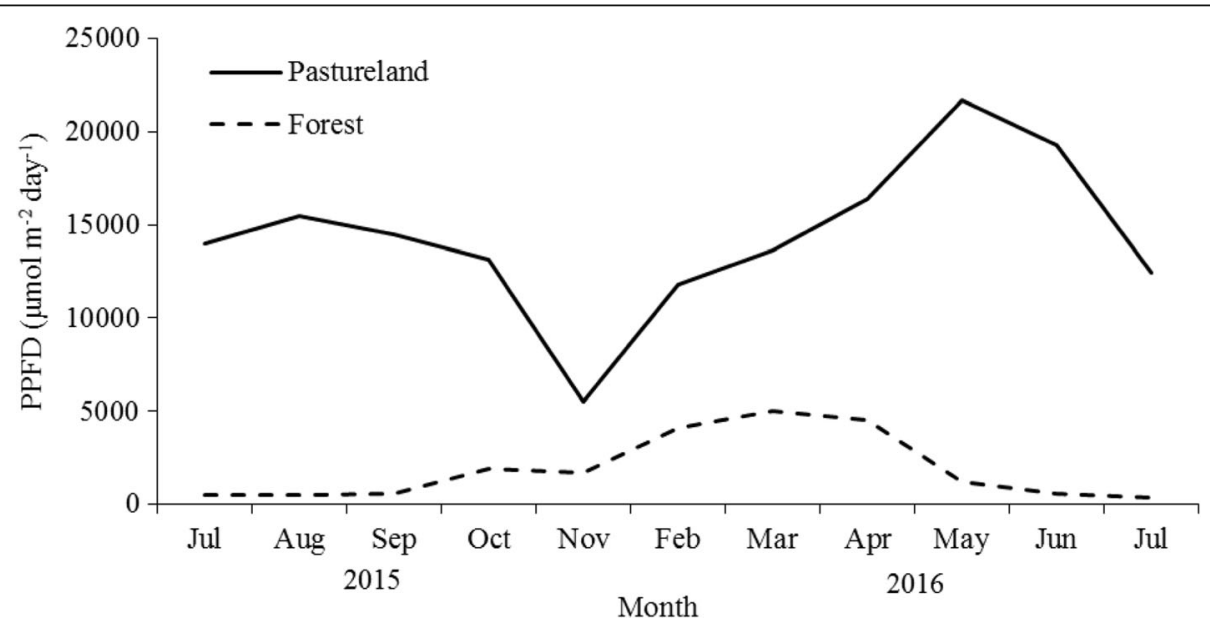

Fig. 5 Seasonal variation of PPFD (photosynthetic photon flux density) in alpine pastureland and temperate deciduous forest 


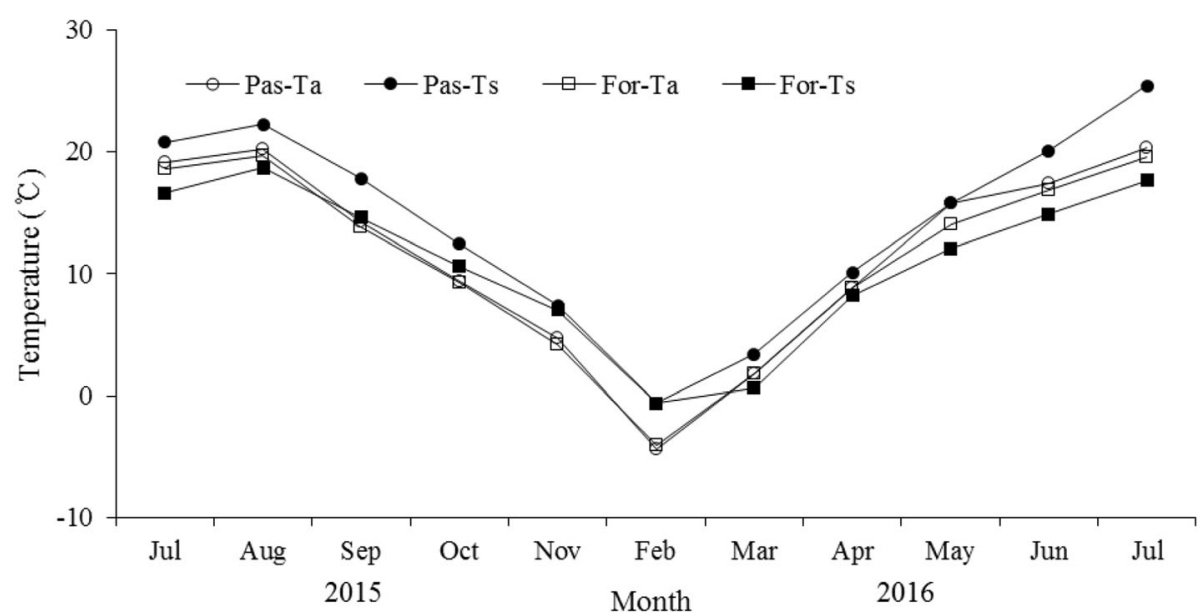

Fig. 6 Variation of air temperature in alpine pastureland (Pas-Ta) and soil temperature in alpine pastureland (Pas-Ts) and air temperature in temperate deciduous forest (For-Ta) and soil temperature in temperate deciduous forest (For-Ts) during the study period

fact that the grassland has more roots, including fibrous root, in the soil close to the surface compared to the forest and therefore a high moisture absorption (Canadell et al. 1996). The soil near to the surface is especially where Rs most actively occurs to the high input of organism content as well as the existence of many plant roots (Pregitzer et al. 1998, Fierer et al. 2003). Also, the TDF has a litter layer and the roots exist deep inside the soil, resulting in higher SMC in the soil surface than AP. According to another study, low SMC in the grassland ecosystem reduces root activity, decreasing root respiration, which in turn reduces Rs whereas the impact is weaker in the forest ecosystem because the roots penetrate deep into the soil (Davidson et al. 2000). However, this study has shown that the correlation between Rs and SMC in the TDF ecosystem is very low (Fig. 8). The correlation between Rs and SMC was also low in the AP, but the study showed there was an exponential correlation during the growth period with the exception of winter period when the temperature is low (Fig. 8). Land-use changes from a TDF to AP did not result in any significant difference in the correlation between Rs and SMC. While another study confirmed a clear linear or exponential correlation for the forest and grassland ecosystems (Epron et al. 1999, Davidson et al. 1998), this study did not find such tendency. This demonstrates that SMC is not the single factor in determining its relationship with Rs but rather in combination with other environmental factors, such as temperature and rainfall events.

ASC changes greatly depending on the land-use changes from forest to grassland or vice versa as well as the grassland management plan (Paul et al. 2002), and it is reported to influence Rs (Sheng et al. 2010, Kellman

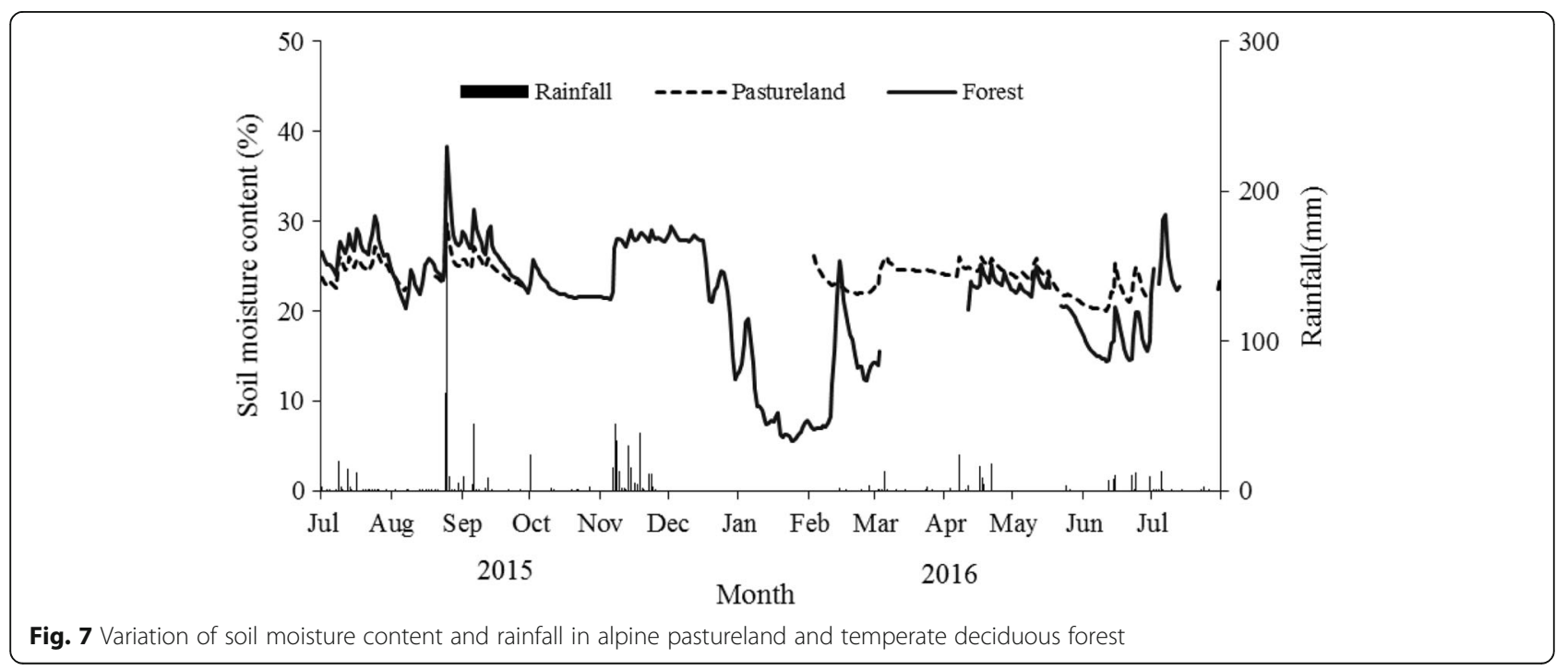




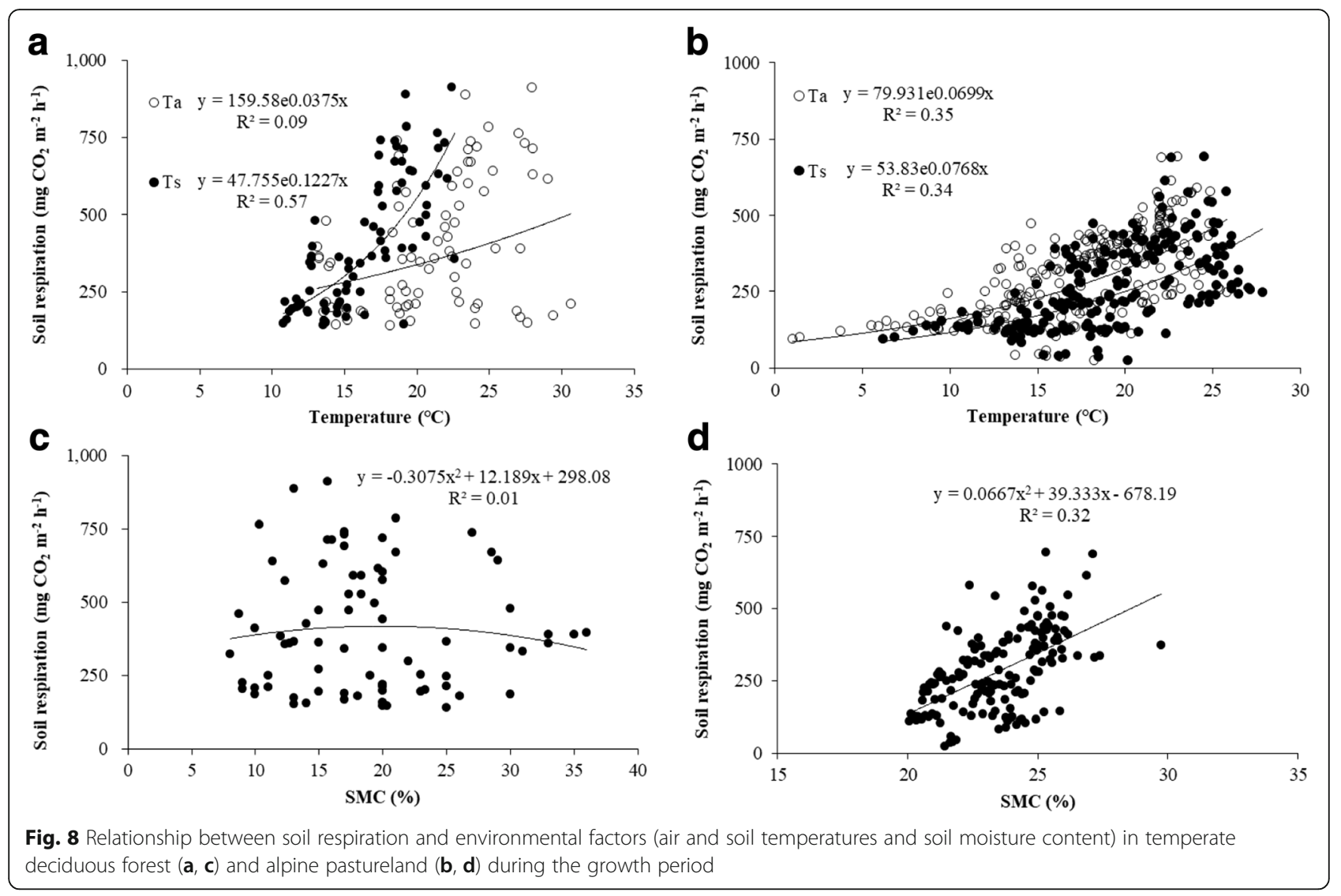

et al. 2007). There is a close relationship between the environments that affect the above-ground and belowground carbon cycles (Hooper et al. 2000, Dixon et al. 1994). The dominant vegetation in an ecosystem increases the overall carbon accumulation in the ecosystem by expanding the above-ground biomass carbon and, at the same time, increases below-ground carbon accumulation by decomposing litter and roots $(\mathrm{Hu}$ et al. 2014). Therefore, the quantification and the study of changing carbon accumulation in the soil caused by the land-use changes are very important in understanding the carbon cycle in an ecosystem. This study's analysis of ASC up to $30 \mathrm{~cm}$ in depth, both the AP and the TDF had higher carbon accumulation closer to the surface (Fig. 4). This is due to higher litter accumulation and root activity closer to the surface, resulting in the concentration of soil microorganism and therefore lots of organic carbon (Raich and Tufekciogul 2000). This study found that ASC was higher in the AP than in the TDF (Fig. 4). This finding is consistent with another study result that has shown that carbon accumulation increases when the land-use changes from a virgin forest to a pastureland (Guo and Gifford 2002). Based on this conclusion, it can be supposed that ASC is low due to the relatively high Rs in the forest in comparison to the grassland (Sheng et al. 2010). As study shows a significant correlation between ASC and Rs in the ecosystem (Hu et al. 2014), more studies need to be conducted combining Rs with carbon accumulation changes arising from land-use changes.

However, since grassland vegetation has characteristics that various plant community patches of different types are connected, it is necessary to investigate more than a certain area (minimum area) to obtain a representative value. However, the soil respiration and environmental factors used in this study have limitations in collecting data in a wide area because many precision measuring instruments are used. In this study, there is a problem that the data on point area cannot be obtained. In order to overcome this problem, this study selected the point where the whole vegetation element is reflected equally in the measurement area and the point where the data is collected is included in the dominant community. In addition, due to the high altitude of the study area, it is very difficult to collect data continuously due to deep snowfall, freezing, lightning, strong winds, wildlife disturbance, etc. For this reason, we have introduced automatic measuring system for Rs and apparatus that can collect continuous data so that as much data as possible is collected. However, despite the above efforts, only limited period data have been 
collected and conclusions have been drawn from them, so there is a limit to the accuracy that can be somewhat low.

\section{Conclusions}

In the world as well as Korea, the artificial transformation of natural ecosystems into different ecosystems is proceeding widely. Land-use changes lead to changes in dominant species life-form leading to photosynthesis systems and microenvironments, which in turn lead to make the different characteristics of carbon cycle and storage in same region. For evaluating and predicting the carbon cycle in the vegetation modified by the human activity, it is necessary to understand the carbon cycle and storage characteristics of natural ecosystems and converted ecosystems.

In this study, we found that the different land-use types in the same region have different features in carbon cycle due to change of various factors, such as Ts, Ta, SMC, ASC, and sunlight, closely related to carbon cycle. In two ecosystems of TDF and AP, the Rs in AP was lower about $54 \%$ than that in the TDF. Also, ASC in the AP was 124.49 $\mathrm{Mg} \mathrm{C} \mathrm{ha}{ }^{-1}$ from litter layer to $30-\mathrm{cm}$ soil depth. The ASC was at $88.9 \mathrm{MgC} \mathrm{ha}^{-1}$, and it was $71.5 \%$ of that of the AP. The average SMC in the 0- to 15- $\mathrm{cm}$ soil depth was higher in the TDF than that in the AP.

From the viewpoint of the carbon cycle and sequestration of the ecosystem, AP showed a greater amount of carbon stored in the soil due to sustained supply of above-ground litters and lower degradation rate (soil respiration) than forests in the high mountains. This shows that forests and grassland do not have much difference in terms of storage and circulation of carbon because the amount of carbon in the forest biomass is stored in the soil in the grassland.

\section{Abbreviations}

AP: Alpine pastureland; ASC: Accumulated soil carbon; Rs: Soil respiration; SMC: Soil moisture content; Ta: Air temperature; TDF: Temperate deciduous forest; Ts: Soil temperature

\section{Acknowledgements}

Not applicable

\section{Funding}

This research was supported by "Cooperative Research Program for Agricultural Science \& Technology Development" Rural Development Administration, Republic of Korea (Project No: PJ01001302).

\section{Availability of data and materials}

Please contact the author for data requests.

\section{Authors' contributions}

All authors conducted a survey together during the study period. The field data was mainly collected by JSH and EJY. LJS wrote the manuscript and examined the manuscript. JYP provided the necessary equipment for the preparation of the survey. All authors read and approved the final manuscript.
Ethics approval and consent to participate

Not applicable

Consent for publication

Not applicable

Competing interests

The authors declare that they have no competing interests.

\section{Publisher's Note}

Springer Nature remains neutral with regard to jurisdictional claims in published maps and institutional affiliations.

\section{Author details}

${ }^{1}$ Department of Biological Science, Konkuk Universtiy, 05029 Seoul, South Korea. ${ }^{2}$ Division of Ecosystem Service \& Research Planning, National Institute of Ecology, Seochon-gun, South Korea.

Received: 31 July 2017 Accepted: 12 January 2018

Published online: 25 January 2018

\section{References}

Batjes, N. H. (2014). Total carbon and nitrogen in the soils of the world. European Journal of Soil Science., 65, 10-21.

Canadell, J., Jackson, R. B., Ehleringer, J. B., Mooney, H. A., Sala, O. E., \& Schulze, E. D. (1996). Maximum rooting depth of vegetation types at the global scale. Decologia, 108, 83-595.

Climatological Normals of Korea. (2011). Korea meteorological administration. Seoul: Climatological Normals of Korea.

Davidson, E., Belk, E., \& Boone, R. D. (1998). Soil water content and temperature as independent or confounded factors controlling soil respiration in a temperate mixed hardwood forest. Global Change Biology, 4, 217-227.

Davidson, E. A., Verchot, L. V., Cattânio, J. H., Ackerman, I. L., \& JEM, C. (2000). Effects of soil water content on soil respiration in forests and cattle pastures of eastern Amazonia. Biogeochemistry, 48, 53-69.

Dixon, R., Brown, S., Houghton, R. E. A., Solomon, A. M., Trexler, M. C., \& Wisniewski, J. (1994). Carbon pools and flux of global forest ecosystems. Science (Washington), 263, 185-190.

Epron, D., Farque, L., Lucot, É., \& Badot, P. M. (1999). Soil $\mathrm{CO}_{2}$ efflux in a beech forest: dependence on soil temperature and soil water content. Annals of Forest Science, 56, 221-226.

Fierer, N., Schimel, J. P., \& Holden, P. A. (2003). Variations in microbial community composition through two soil depth profiles. Soil Biology and Biochemistry, $35,167-176$.

Guo, L. B., \& Gifford, R. M. (2002). Soil carbon stocks and land use change: a meta analysis. Global Change Biology, 8, 345-360.

Hooper, D. U., Bignell, D. E., Brown, V. K., Brussard, L., Mark Dangerfield, J., Wall, D. H., Wardle, D. A., Coleman, D. C., Giller, K. E., Lavelle, P., Van der Putten, W. H., Ruiter, P. C., Rusek, J., Silver, W. L., Tiedje, J. M., \& Wolters, V. (2000). Interactions between aboveground and belowground biodiversity in terrestrial ecosystems: patterns, mechanisms, and feedbacks. Bioscience, 50, 1049-1061.

Houghton, R. A. (1999). The annual net flux of carbon to the atmosphere from changes in land use 1850-1990. Tellus B, 51, 298-313.

Hu, C., Liu, G., Fu, B., Chen, L., Lyu, Y., \& Guo, L. (2014). Soil carbon stock and flux in plantation forest and grassland ecosystems in Loess Plateau, China. Chinese Geographical Science, 24, 423-435.

Jobbágy, E. G., \& Jackson, R. B. (2000). The vertical distribution of soil organic carbon and its relation to climate and vegetation. Ecological Applications, 10, 423-436.

Kellman, L., Beltrami, H., \& Risk, D. (2007). Changes in seasonal soil respiration with pasture conversion to forest in Atlantic Canada. Biogeochemistry, 82, 101-109.

Lloyd, J., \& Taylor, J. A. (1994). On the temperature dependence of soil respiration. Functional Ecology, 8, 315-323.

Luyssaert, S., Schulze, E. D., Börner, A., Knohl, A., Hessenmöller, D., Law, B. E., Ciais, P., \& Grace, J. (2008). Old-growth forests as global carbon sinks. Nature, 455, 213-215.

Michelsen, A., Andersson, M., Jensen, M., Kiøller, A., \& Gashew, M. (2004). Carbon stocks, soil respiration and microbial biomass in fire-prone tropical grassland, woodland and forest ecosystems. Soil Biology and Biochemistry, 36, 1707-1717. 
Musselman, R. C., \& Fox, D. G. (1991). A review of the role of temperate forests in the global $\mathrm{CO}_{2}$ balance. Journal of the Air \& Waste Management Association, $41,798-807$.

Noh, T. H., Han, B. H., Kim, J. Y., Lee, M. Y., \& Yoo, K. J. (2013). Actual vegetation and structure of plant community in Daegwallyeong ranch, Gangwondo(province). Korean Journal of Environment and Ecology, 27, 579-591.

Ohashi, M., Gyokusen, K., \& Saito, A. (2000). Contribution of root respiration to total soil respiration in a Japanese cedar (Cryptomeria japonica D. Don) artificial forest. Ecological Research, 15, 323-333.

Pachauri, R. K., Allen, M. R., Barros, V. R., Broome, J., Cramer, W., Christ, R., Church, J. A., Clarke, L., Dahe, Q., Dasgupta, P., Dubash, N. K., Edenhofer, O., Elgizouli, I. , Field, C. B., Forster, P., Friedlingstein, P., Fuglestvedt, J., Gomez-Echeverri, L., Hallegatte, S., Hegerl, G., Howden, M., Jiang, K., Jimenez Cisneroz, B., Kattsov, V., Lee, H., Mach, K. J., Marotzke, J., Mastrandrea, M. D., Meyer, L., Minx, J., Mulugetta, Y., O'Brien, K., Oppenheimer, M., Pereira, J. J., Pichs-Madruga, R., Plattner, G. K., Pörtner, H. O., Power, S. B., Preston, B., Ravindranath, N. H., Reisinger, A., Riahi, K., Rusticucci, M., Scholes, R., Seyboth, K., Sokona, Y., Stavins, R., Stocker, T. F., Tschakert, P., van Vuuren, D., \& van Ypserle, J. P. (2014). Climate change 2014: synthesis report. Contribution of working groups I, II and III to the fifth assessment report of the intergovernmental panel on climate change. Geneva: IPCC Secretariat.

Paul, K. I., Polglase, P. J., Nyakuengama, J. G., \& Khanna, P. K. (2002). Change in soil carbon following afforestation. Forest Ecology and Management, 168, 241-257.

Pregitzer, K. S., Laskowski, M. J., Burton, A. J., Lessard, V. C., \& Zak, D. R. (1998). Variation in sugar maple root respiration with root diameter and soil depth. Tree Physiology, 18, 665-670

Protocol, K. (1997). United Nations framework convention on climate change. Kyoto: Kyoto Protocol.

Pumpanen, J., Kolari, P., Ilvesniemi, H., Minkkinen, K., Vesala, T., Niinistö, S., Lohila, A., Larmola, T., Morero, M., Pihlatie, M., Janssens, I., Yuste, J. C., Grünzweig, J. M., Reth, S., Subke, J. A., Savage, K., Kutsch, W., Østreng, G., Ziegler, W., Anthoni, P., Lindroth, A., Hari, P., \& Janssens, I. (2004). Comparison of different chamber techniques for measuring soil $\mathrm{CO}_{2}$ efflux. Agricultural and Forest Meteorology, 123, 159-176.

Raich, J. W., \& Tufekciogul, A. (2000). Vegetation and soil respiration: correlations and controls. Biogeochemistry, 48, 71-90.

Sheng, H. A. O., Yang, Y., Yang, Z., Chen, G., Xie, J., Guo, J., \& Zou, S. (2010). The dynamic response of soil respiration to land-use changes in subtropical China. Global Change Biology, 16, 1107-1121.

Suh, S. U., Chun, Y. M., Chae, N. Y., Kim, J., Lim, J. H., Yokozawa, M., Lee, M. S., \& Lee, J. S. (2006). A chamber system with automatic opening and closing for continuously measuring soil respiration based on an open-flow dynamic method. Ecological Research, 21, 405-414.

Suseela, V., Conant, R. T., Wallenstein, M. D., \& Dukes, J. S. (2012). Effects of soil moisture on the temperature sensitivity of heterotrophic respiration vary seasonally in an old-field climate change experiment. Global Change Biology, 18, 336-348.

Vesterdal, L, Elberling, B., Christiansen, J. R., Callesen, I. \& Schmidt, I. K. (2012). Soil respiration and rates of soil carbon turnover differ among six common European tree species. Forest Ecology and Management, 264, 185-196.

Wang, G., Qian, J., Cheng, G., \& Lai, Y. (2002). Soil organic carbon pool of grassland on the Qinghai-Tibetan plateau and its global implication. Science of the Total Environment, 291, 207-217.

Wang, C., Yang, J., \& Zhang, Q. (2006). Soil respiration in six temperate forests in China. Global Change Biology, 12, 2103-2114.

White, R. P., Murray, S., Rohweder, M., Prince, S. D., \& Thompson, K. M. (2000). Grassland ecosystems (p. 81). Washington DC: World Resources Institute.

Wildung, R. E., Garland, T. R., \& Buschbom, R. L. (1975). The interdependent effects of soil temperature and water content on soil respiration rate and plant root decomposition in arid grassland soils. Soil Biology and Biochemistry, 7, 373-378.

Wu, Y., Liu, G., Fu, B., Liu, Z., \& Hu, H. (2006). Comparing soil $\mathrm{CO}_{2}$ emission in pine plantation and oak shrub: dynamics and correlations. Ecological Research, 21, 840-848.

Xu, Z., Tang, S., Xiong, L., Yang, W., Yin, H., Tu, L., Wu, F., Chen, L., \& Tan, B. (2015). Temperature sensitivity of soil respiration in China's forest ecosystems: Patterns and controls. Applied Soil Ecology, 93, 105-110.

\section{Submit your next manuscript to BioMed Central and we will help you at every step:}

- We accept pre-submission inquiries

- Our selector tool helps you to find the most relevant journal

- We provide round the clock customer support

- Convenient online submission

- Thorough peer review

- Inclusion in PubMed and all major indexing services

- Maximum visibility for your research

Submit your manuscript at www.biomedcentral.com/submit
( ) BioMed Central 